Cite as: Osman M. Jama, Guijian Liu, Abdishakur W. Diriye, Balal Yousaf, Ibrahim Basiru \& Abdulhakim M. Abdi (2020): Participation of civil society in decisions to mitigate environmental degradation in post-conflict societies: evidence from Somalia, Journal of Environmental Planning and Management, DOI: https://

doi.org/10.1080/09640568.2019.1685957

\title{
Participation of civil society in decisions to mitigate environmental degradation in post-conflict societies: evidence from Somalia
}

\author{
Osman M. Jama ${ }^{\text {a,b }}$, Guijian Liu ${ }^{\star, a, c}$, Abdishakur W. Diriye ${ }^{a}$, Balal Yousaf ${ }^{c}$, \\ Ibrahim Basiru ${ }^{a}$ and Abdulhakim M. Abdi ${ }^{\mathrm{d}}$ \\ ${ }^{\mathrm{a}}$ School of Public Affairs, University of Science and Technology of China, Hefei, People's \\ Republic of China; ${ }^{\mathrm{b}}$ Department of Public Administration, Faculty of Economics and \\ Management Science, Mogadishu University, Mogadishu, Somalia; 'School of Earth and Space \\ Sciences, University of Science and Technology of China, Hefei, People's Republic of China; \\ ${ }^{\mathrm{d}}$ Centre for Environmental and Climate Research, Lund University, Lund, Sweden
}

\begin{abstract}
The question of the degree to which participation by civil society contributes to environmental decisions in post-conflict societies has received little attention. This study sheds light on the extent to which degrees of participation contribute to environmental decision-making in the Puntland State of Somalia using questionnaire surveys. We found that active participation has the highest contribution to environmental decisions. Our findings also indicated that the most pressing forms of environmental degradation in Puntland, as perceived by the respondents, are land degradation, drought related to the scarcity of rainfall, and deforestation. This study recommends "environmental cooperation" built into the peace-building process as a clear-cut concept to tackle both environmental degradation and conflicts. At the core of this concept is active participation and collaboration between civil society and the government as a means of mitigating environmental degradation in post-conflict Somalia. This will result in favorable environmental conditions and sustainable peace.
\end{abstract}

Keywords: Somalia; Puntland; civil society; environmental degradation; post-conflict

\section{Introduction}

Principle 10 of the Rio Declaration on Environment and Development sets out three "Procedural Environmental Rights", which are (1) access to information, (2) access to participation, and (3) access to environmental justice, as key mainstays of sound environmental decisions (Salamon, Sokolowski, and List 2003). With regards to these fundamental rights, greater civil society participation has been advocated both in the academic literature and policy discussions (Betsill and Elisabeth 2008; O'Faircheallaigh 2010).

In recent years, there has been an increase in developing countries putting forward policies allowing civil society participation in environmental policy-making. This increase has been the result of both civil societies' request for full participation in the environmental decisions that impact their lives and government recognition of the importance of civil society involvement in the environmental policy-making process (Charnley and Engelbert 2005). For instance, there has been an increase in participatory

*Corresponding author. Email: lgj@ustc.edu.cn 
environmental decision-making in some African countries as a result of dissatisfaction with "top-down" government methods in environmental governance (AfDB 2016). These increases are thought to be caused by two factors. The first is the failure of African states to prevent over-exploitation and ineffective utilization of natural resources, and the second is frustration over the ineffectiveness of government-run conservation projects. As a result, civil society participation has become an emerging matter of interest in Africa. Numerous African countries and regions have started initiatives to stimulate civil society participation in environmental issues (AfDB 2016). Increased participation in environmental decisions is particularly important in post-conflict countries such as Somalia where public institutions and rule of law have entirely broken down and environmental degradation has developed into a pressing state of affairs that needs to be mitigated (Menkhaus 2007, 2014).

Although civil society cannot fulfill all roles that government plays in post-conflict transitions, civil society organizations provide an important role in post-conflict contexts, both in conservation and environmental protection in the absence of effective state reach and in rebuilding the relationship between the state and broader society (Fagan 2006). Studies have shown that participation by civil society is one of the most vital issues that determines whether post conflict initiatives will be successful and sustainable (Francois 2017). For instance, while state officials or international leaders can be ignorant of the impact of the cultural context under which they are implementing a post-conflict initiative, participation by civil society may allow them to understand the cultural context of specific community attributes (Parver et al. 2008).

Empirical research has found that participation by civil society as a stakeholder in environmental issues leads to better environmental decision-making (Challies et al. 2017; Reed 2008; Newig and Fritsch 2009; Charnley and Engelbert 2005). Although some scholars point out that participation by civil society can, in certain conditions, lead to negative effects (Newig et al. 2018). For instance, Cooper and Elliott (2003) reported in the Philippines that there were cases where civil society members pursued their self-interest, which led to conflicts and opposition within the community. In Indonesia and Malaysia, participation based on face-to-face and interpersonal relations with government institutions caused conflict between civil society organizations in areas where projects were supposed to be implemented and government institutions that run the projects (Boyle 1998). Thus, some observers have argued that the success of participation would be evaluated by its capacity to improve environmental decisions and not by the participation itself (Beierle and Cayford 2002).

However, the question of the degree to which participation contributes to environmental decisions in post-conflict societies is surprisingly unanswered, or has received little attention (Beierle and Cayford 2002; Newig 2007). The situation in Somalia is particularly unexplored due to the ongoing 28-year conflict. With that in mind, the objective of this study is to explore the extent to which degrees of participation contribute to environmental decision-making in the Puntland State of Somalia.

The first step in examining civil society participation in the context of post-conflict environmental scenarios is describing exactly what types of civil society exist, who the participants are, and how the participation is performed. Thus, in the broadest sense, civil society has been defined as an aggregate of non-state actors unconstrained by government interference of any form (Salamon, Sokolowski, and List 2003; Gemmil and Bamidele-Izu 2002). According to the United Nations Commission on Sustainable Development, this definition includes non-governmental organizations (NGOs), community-based organizations (CBOs), faith-based organizations, environmental groups, 
think tanks, workers and trade unions, academics, business associations, media, women's associations, and youth groups. On the other hand, participation in post-conflict settings is understood to be implemented in a three-dimensional way, where the public authorities or international organizations extend the decision-making process to a range of stakeholders or actors such as experts, representatives of organized groups or individual citizens. This formulates communication and collaboration where the direction of interaction is a one-way delivery of information and the power delegation of the participants to influence the environmental decision-making is limited (Aitken 2010).

This study examines the degrees to which civil society participation contributes to environmental decisions in post-conflict Somalia and perceptions of environmental degradation in Somalia. In particular, this study emphasizes how collaborative solving of environmental problems could aid the recovery process by providing an important opportunity to promote good governance. This is done by addressing lawlessness, repairing trust, improvement in the legitimacy of governing institutions, and simultaneously creating favorable environmental conditions and sustainable peace.

The remainder of this article is as follows: In the second section, we describe the theoretical background followed by the status of Somali civil society. In the third section, we report on the methodology, including hypotheses and statistical modeling. In the fourth section, the results are presented. In the fifth section, the results are discussed within a broader context and in relation to other studies. In the sixth section, the conclusion, implications and limitations are presented.

\section{Theoretical background}

\subsection{Environmental peace-building}

A mounting body of literature on environmental conflict has examined the potential linkage between environmental degradation, resource scarcity, and conflict (Buchanan 2013; Farrell 2017), but arguably a significant restriction of this theory has been its inability to identify the existence of opportunities for cooperation between the actors in a coupled human-environment system (Conca and Dabelko 2002). An emergent alternative theory is that environmental degradation has the potential to lead environmental cooperation resulting in lasting peace (Conca and Wallace 2009; Ide 2017). The theory of environmental peace-building has put forward three strands of scholarship in which environmental cooperation may generate peace-building opportunities (Ogden 2018). The first concerns the prospect that environmental cooperation in places with environmental security can encourage common-pool resource management and conservation initiatives (Ogden 2018; Conca and Wallace 2009; Ide 2018; Conca and Dabelko 2002). Such initiatives can contribute to the prevention of conflicts that occur due to the over-exploitation of natural resources or livelihood insecurities due to environmental pressure (Ide 2017). The second is that collective environmental concerns can lead to a dialogue between conflicting interests, which can then spill over into different areas (Ogden 2018; Conca and Wallace 2009; Ide 2018; Conca and Dabelko 2002). For instance, the UN identifies environmental degradation as a risk factor for violent conflict, while environmental protection of common resources is recognized as a mechanism to build peace (Conca and Wallace 2009). The third is the notion that even conflicts where environmental degradation is not the root cause of the armed con-

flict, continuous environmental monitoring and environmental cooperation between the communities and governments can promote sustainable peace (Carius 2006; Conca and 
Wallace 2009; Conca and Dabelko 2002; Ogden 2018). The majority of environmental cooperation practices have been observed in transboundary international conflicts such as Palestine and Israel (Ide 2017), Peru and Ecuador (Kakabadse, Caillaux, and Dumas 2016), Serbia and Croatia (Ruckstuhl 2010), India and Pakistan (Ali 2013), and Armenia and Azerbaijan (Carius 2006). However, there are some successful cases within individual countries where non-state actors, as representatives of the larger community, worked jointly with the government to manage shared natural resources and that cooperation between non-state actors and the government prevented the eruption of violent conflict. In Yemen, for instance, rival communities worked with non-state actors and established a proper cooperative mechanism to protect shared water resources, which mitigated disputes linked to water scarcity (Taher et al. 2012). Similar cases have been reported from Kenya (Adano et al. 2012), Ethiopia (Bogale and Korf 2007), Afghanistan, Liberia and DR Congo (Burt and Keiru 2011).

\subsection{The status of Somali civil society}

Before the collapse of the Somali state in 1991, it was questionable whether the notion of civil societies existed in the country, because community structures that were selfassured and autonomous from the state were rare (Paffenholz and Spurk 2006). During the tenure of Siad Barre (1969-1991), fully independent civil society organizations were forbidden and those that existed were under the patronage of the state (Harvey 1998). One of the earliest civil society organizations was created in the early 1980s as a response to the humanitarian crisis in the Ogaden region, which resulted from the Somali-Ethiopian War of 1977. By the late 1980s, there were only around 15 local NGOs in the entire country, which increased to over 320 NGOs by 1995 (UNDP 2001). This growth of civil society organizations followed the collapse of the Somali state and the subsequent famine of 1991-1992. With the disappearance of the state, a vibrant civil society emerged and the traditional concept of civil society was challenged and gradually sidelined by a different approach in the form of umbrellas of non-state actors (NSAs). These NSAs had categories such as non-governmental organizations, religious organizations, social and community organizations, environmental organizations, and professional associations (e.g. lawyers, journalists, teachers, etc.).

In the relatively stable regions of Puntland and Somaliland, a vibrant civil society emerged that filled the public service gap (UNDP 2001), and civic or community organizations were increasingly regarded as non-state actors (Menkhaus 2014). The protection, monitoring, advocacy, social cohesion, ecosystem service delivery and environmental awareness by civil society organizations such as African Development Solutions (ADESO) and Candlelight for Health, Education and Environment (CHEE) had been commonplace for protecting the environment. For instance, in Puntland, the advocacy work of ADESO reached a notable accomplishment after the state banned the export of charcoal in 2002, which was driving deforestation in the area (Oduori, Alim, and Gomes 2006). ADESO also introduced solar cooking technology to promote the use of parabolic solar cookers as part of its anti-charcoal campaign. On the other hand, CHEE was heavily involved in the rehabilitation of grazing and forestry resources in Somaliland. These results are due to both organizations efficiently mobilizing local community environmental awareness, collecting and disseminating information, policy consultation, development and implementation, assessment and monitoring, advocacy for environmental justice, and maintaining general public support 
(Malinowski 2014; Gemmil and Bamidele-Izu 2002). Albeit civil society accomplished these social services in a voluntary capacity, their inclusion in the different peacebuilding, democratization and reconciliation processes has yielded positive results in both Puntland and Somaliland (UNDP 2014). The rising influence of civil society seems to be encouraged by the absence of strong central governance in Somalia, yet little is known about their access to environmental decision-making.

\section{Methodology}

\subsection{Description of the study area}

This study was conducted in the Puntland State of Somalia, an autonomous region under the Federal Republic of Somalia (Figure 1). It lies in an arid area that borders the Gulf of Aden to the north, Somaliland to the west, Ethiopia to the southwest, and the Indian Ocean to the east. According to the latest (2017) report from the Puntland department of statistics ${ }^{1}$ under the Ministry of Planning, and International Cooperation,

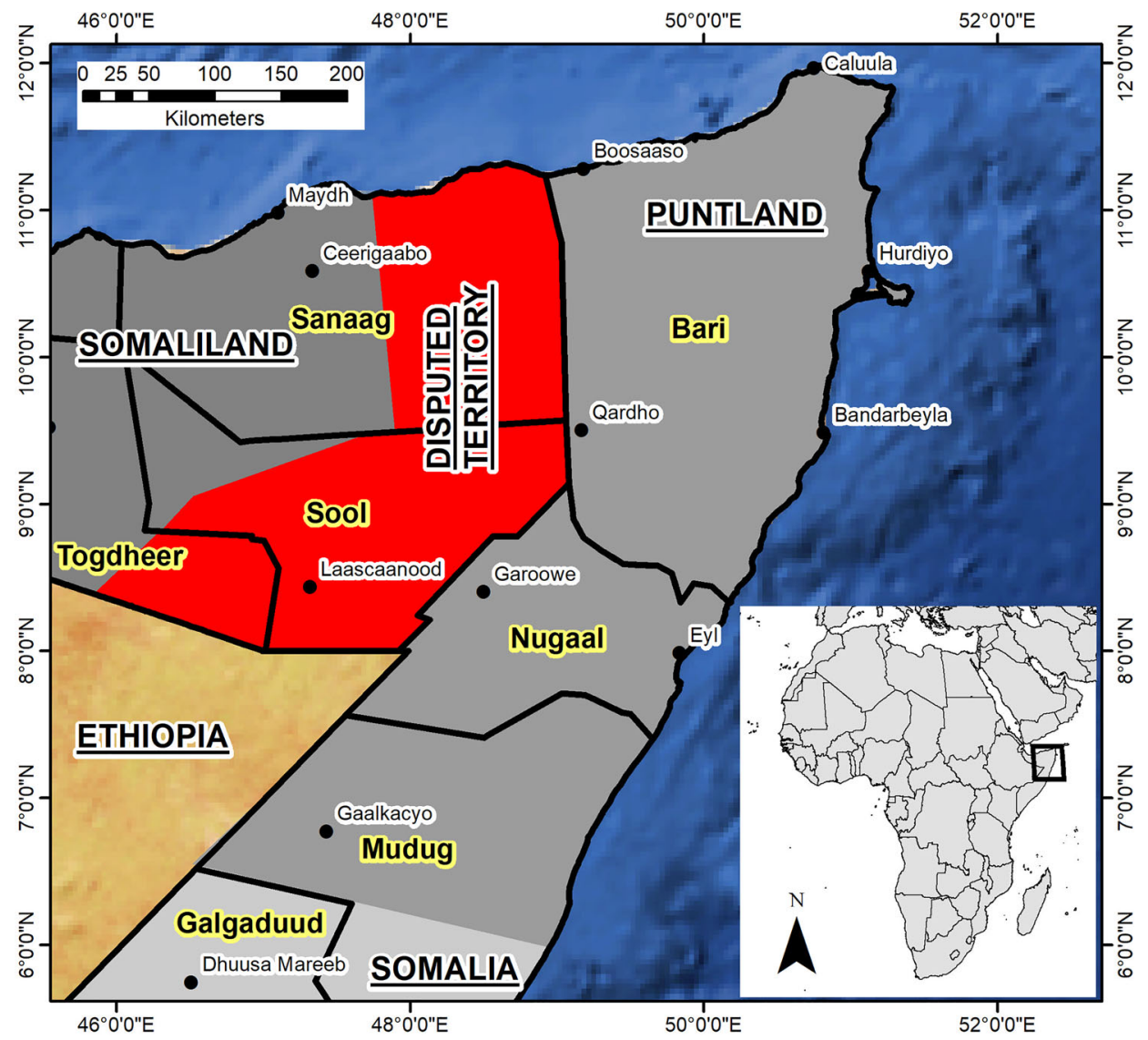

Figure 1. Map of the study area. The Puntland State of Somalia (medium grey) forms the "horn" portion of the Federal Republic of Somalia. The self-declared Republic of Somaliland (dark grey), which is internationally recognized as part of Somalia, is to the west of Puntland and there is a disputed territory (red) between these two Somali Sub-regions. The rest of Somalia (light grey) lies to the South. Colour online. 
the population of Puntland is 4,334,633. Thirty-nine percent of the population comprises pastoral nomads, $38 \%$ are urban, $20 \%$ are rural, and 3\% live in camps for internally displaced people (IDPs). The productivity of crops and pasture in Puntland is dependent on erratic rainfall that is under the influence of large-scale climatic teleconnections such as the El Ninõ-Southern Oscillation (Abdi et al. 2016) and the Indian Ocean Dipole (Marchant et al. 2007). The average annual temperature is $30^{\circ} \mathrm{C}$, but can reach $47^{\circ} \mathrm{C}$ along the coastal zones, and average annual rainfall is around $180 \mathrm{~mm}$. Droughts occur every 2-3 years and are often followed by seasonal floods in the dry river valleys.

\subsection{Data collection}

The principal research tool was a survey questionnaire. The questionnaires contained three main sections. The first section was aimed at gathering the demographic characteristics of the respondents. The second section related to the perceptions of the respondents regarding their environment. In this section, different questioning techniques were used, such as Likert scale, polar questions and multiple response, to understand respondents' perceptions of environmental degradation, their environmental awareness, participation and influence in environmental decision-making, and their ideas on the entity responsible for tackling environmental degradation. These were supplemented by follow-up questions contingent on respondent answer. The third section related to the causal model containing four Likert scale subsections comprising a total of sixteen items based on a scale ranging from "strongly agree" to "strongly disagree."

A pilot study was deployed with a small number of recipients $(n=30)$ before commencing the full data collection to enhance the clarity and reliability of the survey. The primary data collection was conducted using both online and printed questionnaires. Initial emails were sent to the target civil society members in order to introduce the research purpose, basic instructions of how to complete the online survey form, and the link to the online questionnaire which was written in clear and concise language that was easily understandable (see survey questionnaire in the Supplementary material). We chose an online survey as our main data gathering instrument considering its advantages such as time, cost, reduction in data entry error and accessibility as $68 \%$ of our target demographic, i.e. educated Somalis, use the Internet on a weekly basis (USAGM 2013). We also distributed paper-based survey questionnaires as an alternative to the online forms. Secondary data were collected through accessible online databases (i.e. Web of Science, Scopus, Google Scholar, and the University of Science and Technology's Online Library).

Before we conducted the survey, we calculated the sample size according to the number of variables and parameters in the survey questionnaire (Bruce and Chambers 2002; Loehlin 2004). We followed the approach by Wang et al. (2019) and computed a sample size of 640 based on our 4 variables and 16 parameters (see survey questionnaire in the Supplementary material). Between November and December 2018, we sent 640 invitations to civil society members under the umbrella of Puntland Non-State Actors Association (PUNSAA), asking them to participate in the study. PUNSAA was chosen as a sample source because it has been shown that civil society organizations who are members of umbrella associations are regularly active in government policy-making (EUSU 2012). We did not include traditional elders as civil society members, since our target respondents were younger, educated Somalis. Furthermore, there is doubt about traditional elders being a separate organized civil society group (Menkhaus 2003). 
The members were given the choice to respond online, through an online questionnaire survey platform (www.jotform.com), or using printed questionnaires that were distributed in the field. We received a total of 289 responses, of which 267 were completed online and 21 were completed through using paper. The majority of the responses were from the Nugaal, Bari, and Mudug regions. So, to increase the response rate and encourage an equitable treatment of underrepresented civil society members we sent another round of reminder invitations (320) in January 2019 and we received 61 completed responses, of which 13 were paper responses and 48 were online responses. Altogether, we received 350 responses: 316 online and 34 on paper. Thirty-seven were discarded due to missing values and our final set was 313 complete responses to use for further analysis.

\subsection{Statistical analysis}

The variables included in the statistical analysis are provided in Table 1. First, we used Pearson's product-moment correlation to check the presence of relationships between variables. Then, we used a stepwise regression analysis that consists of a forward component to measure the contribution of predictors, and a backward component to identify and drop the variable that has the least influence on the response. The objective of this analysis was to choose the combination that explains the most variance in the response.

Before running the regression, we checked the data for normality and assessed the variables for multicollinearity using the variance inflation factor (VIF). Since the sample size is relatively small, we built regression models for each independent variable to determine the predictor that contributes the most to the response variable. The variables in the regression analysis are defined as follows:

environmental decisions ( $Y$ ): A process of assessing how social, political, and governing systems affect the natural environment in order to create a win-win situation for environment and society (Welp, Kasemir, and Jaeger 2009).

information $\left(X_{1}\right)$ : A passive one-way relationship whereby the government disseminates information on policy (OECD 2001).

consultation $\left(X_{2}\right)$ : A limited participation whereby the government asks for, and obtains, citizen feedback on policy through discussions, comments, expression of public opinion, and surveys (OECD 2001).

active participation $\left(X_{3}\right)$ : A two-way communication based on the principle of partnership, whereby organized citizens actively engage in the decision-making process

Table 1. Means, standard deviations (SD), and Pearson correlations $(r)$ among environmental decisions (ED), information (I), consultation (C), active participation (AP).

\begin{tabular}{lcccccr}
\hline Variable & Mean & SD & ED & I & C & AP \\
\hline Environmental decisions & 1.881 & 0.557 & 1 & & & \\
Information & 2.927 & 0.66 & $0.146^{* *}$ & 1 & & \\
Consultation & 2.373 & 0.665 & $0.345^{* *}$ & $0.314^{* *}$ & 1 & \\
Active Participation & 2.321 & 0.567 & $0.509^{* *}$ & $0.268^{* *}$ & $0.372^{* *}$ & 1 \\
\hline
\end{tabular}

Note: ${ }^{* *}$ Correlation is significant at the 0.01 level. 
by proposing policy options and the responsibility for policy formulation and implementation rests under the government (OECD 2001). This variable signifies the involvement of civil society in the governance system, particularly in the environmental decision-making process, for the purpose of exerting influence in the final decisions or simply inclusiveness at its highest level.

The null hypothesis (H0) is that none of the independent variables significantly contribute to $\mathrm{Y}$. The alternative hypothesis (Ha) is that at least two of the independent variables significantly contribute to $\mathrm{Y}$. Thus, the multiple linear regression is represented in Equation (1) as:

$$
y=\beta_{1} X_{1}+\beta_{2} X_{2}+\beta_{3} X_{3}+\varepsilon
$$

where $y$ is the response variable (environmental decisions); $\beta_{0}$ is the intercept; $\beta_{1}$ is the coefficient of first predictor $X_{1}$ (information); $\beta_{2}$ is the coefficient of second predictor $X_{2}$ (consultation); $\beta_{3}$ is the coefficient of third predictor $X_{3}$ (active participation); $\varepsilon$ is an error term.

Consolidating the multiple linear regression with our hypothesis yields:

$$
\begin{aligned}
& \mathbf{H 0}=\beta_{1}+\beta_{2}+\beta_{3}=0 \\
& \mathbf{H a}=\text { At least one paired combination of } \beta_{1}, \beta_{2} \text {, and } \beta_{3} \text { does not equal to } 0
\end{aligned}
$$

\section{Results}

\subsection{Respondent demography}

As presented in Table 2, participants of the study were dominated by male respondents $(n=234,74.8 \%)$ compared to female respondents $(n=79,25.2 \%)$. The dominance of male respondents could be due to the fact that girls generally have fewer opportunities for education than boys in Somalia (UNICEF 2017); and this disparity remains as children get older. The age of the majority of respondents was between 18 and 50 years $(n=296,94.5 \%)$. The respondents in the study were reasonably well-educated. Eighteen $(5.7 \%)$ had attained education up to high school, $36(11.5 \%)$ had a diploma, 139 (44.4\%) had a bachelor degree, $113(36.1 \%)$ had a master's degree, and $7(2.2 \%)$ had a doctorate. Respondents were generally from the major cities of Puntland and all the sub-regions were represented: Mudug $(n=60,19 \%)$, Nugaal $(n=96,38 \%)$, Bari $(n=66,21 \%)$, Sanaag $(n=36,12 \%)$, Sool $(n=30,10 \%)$, others $(n=25,8 \%)$. All the participants in the study were members of civil society organizations. They were subdivided into community organizations $(20.8 \%)$, NGOs $(16.6 \%)$, business associations $(14.1 \%)$, academia (12.1\%), professional associations $(10.9 \%)$, policy think tanks $(9.6 \%)$, human rights groups $(4.5 \%)$, women's associations $(2.2 \%)$, faith-based organizations $(1 \%)$, trade unions $(0.6 \%)$, and others $(7.7 \%)$.

\subsection{Responses to key questions on environmental degradation}

Overall awareness of the respondents to environmental degradation indicates $75 \%$ of male and $25 \%$ of female respondents are aware of degradation taking place in their environment (Figure 2). We did not find a major difference in views between male and female respondents concerning their awareness of environmental degradation, 
Table 2. Demographics of the survey participants.

\begin{tabular}{lrrrrr}
\hline Variable & $N$ & Percentage, $\%$ & \multicolumn{1}{c}{ Variable } & $N$ & Percentage, \% \\
\hline Gender & & & Age & & \\
$\quad$ Male & 234 & 74.8 & $18-30$ & 146 & 46.6 \\
Female & 79 & 25.2 & $31-40$ & 122 & 39 \\
& & & $41-50$ & 28 & 8.5 \\
& & $51-60$ & 16 & 5.1 \\
Education & & & C1+ & 1 & 0.3 \\
High School & 18 & 5.5 & Comil Society & 65 & 20.8 \\
Diploma & 36 & 11.3 & NGO & 52 & 16.6 \\
Bachelor degree & 139 & 44.4 & Business associations & 44 & 14.1 \\
Master's degree & 113 & 36.1 & Academia & 38 & 12.1 \\
Doctorate & 7 & 2.2 & Professional associations & 34 & 10.9 \\
& & & Policy think tanks & 30 & 9.6 \\
& & Human rights groups & 14 & 4.5 \\
& & Women's associations & 7 & 2.2 \\
& & Faith-based organizations & 3 & 1 \\
& & Trade unions & 2 & 0.6 \\
& & Others & 24 & 7.7 \\
& & Total & 313 & 100 \\
\hline
\end{tabular}

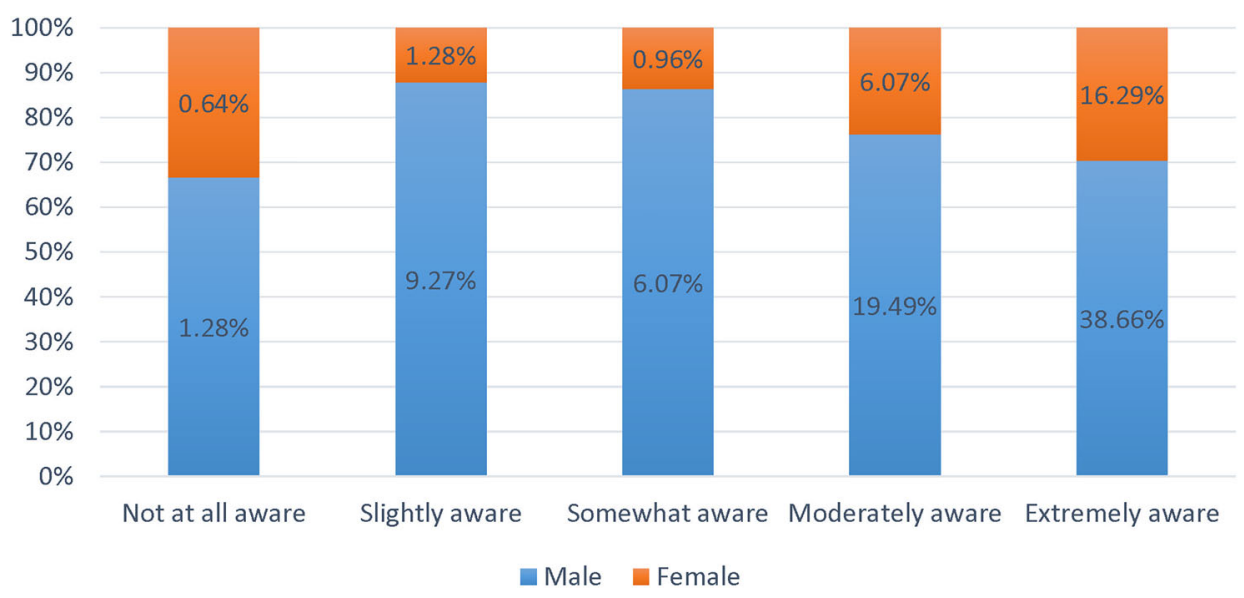

Figure 2. Level of environmental awareness amongst the survey participants. These figures are among the $75 \%$ of male and $25 \%$ of female respondents who are aware of environmental degradation.

since the total number of females in the study is lower than that of males. Out of the $75 \%$ of male respondents, $39 \%$ were extremely aware, $20 \%$ were moderately aware, $6 \%$ were somewhat aware, $9 \%$ were slightly aware and $1 \%$ of them were not aware of environmental degradation. Whereas for the $25 \%$ of female respondents, $16 \%$ were extremely aware, $6 \%$ were moderately aware, and $3 \%$ of the respondents were somewhat aware, slightly aware or not aware of environmental degradation.

The specific concerns of the respondents regarding the environment in Puntland are shown in Figure 3. The respondents ranked the most serious environmental concern in the state as land degradation (93.9\%) followed by drought related to rainfall $(81.6 \%)$, deforestation $(81.3 \%)$, desertification $(63.5 \%)$, water scarcity related to 


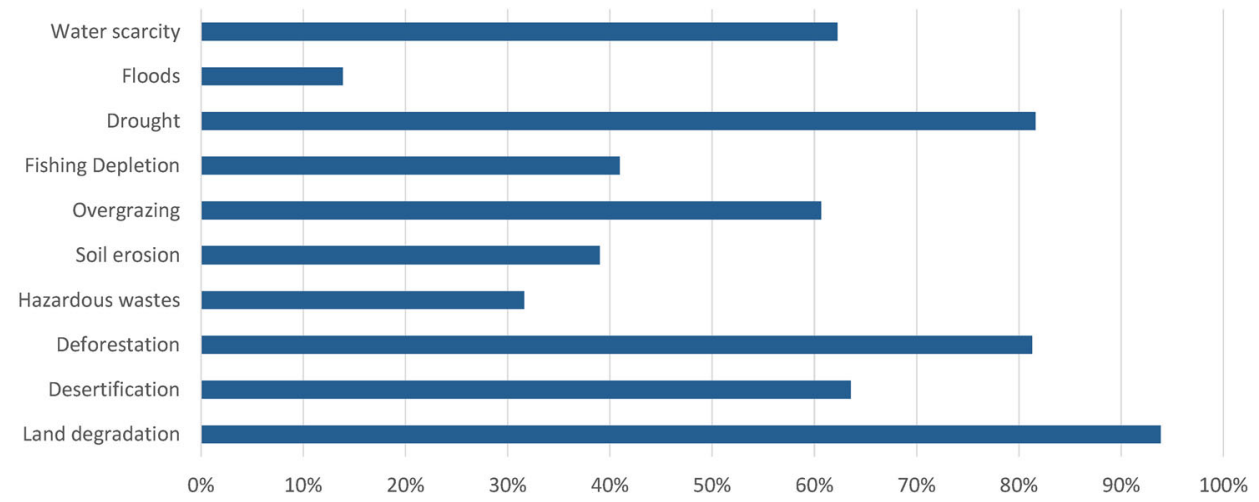

Figure 3. The most prominent forms of environmental degradation in Puntland as perceived by the survey respondents. Of these, land degradation (93.9\%), drought related to rainfall $(81.6 \%)$, and deforestation $(81.3 \%)$ were the most pressing in the region.

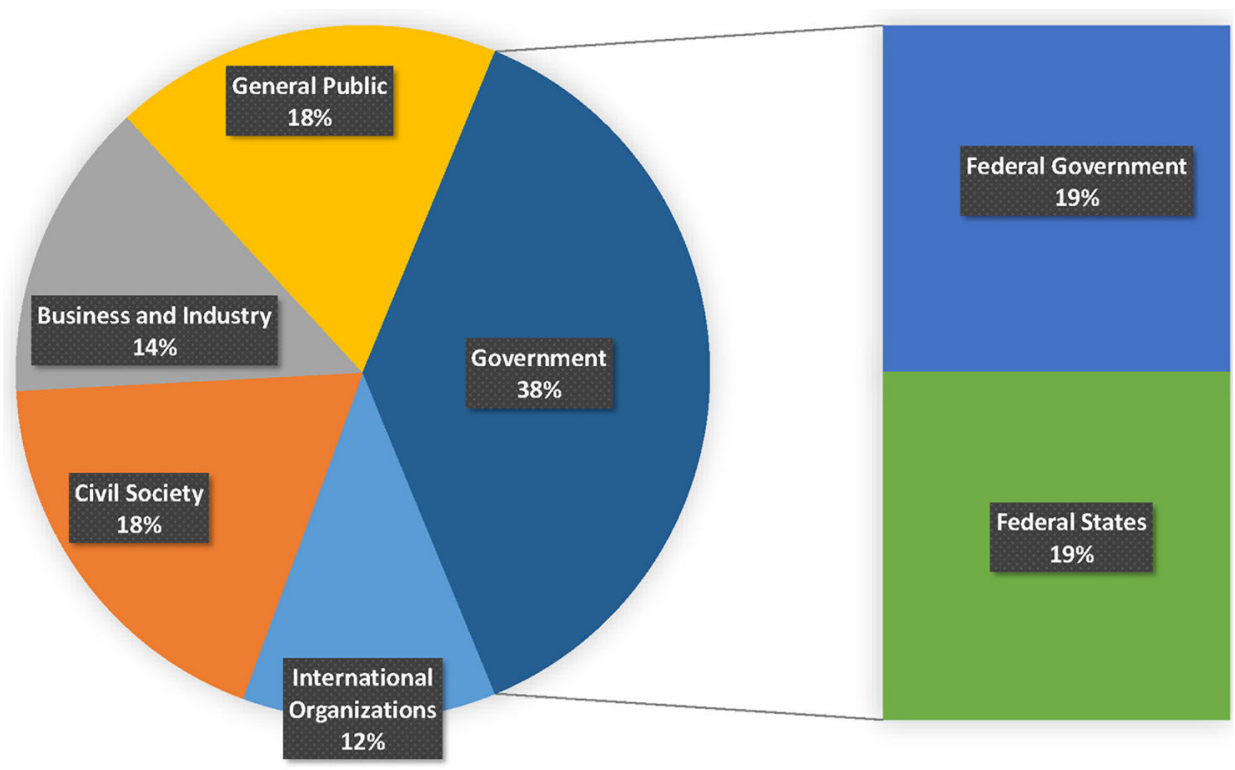

Figure 4. Respondent perceptions regarding the attribution of responsibility for tackling environmental degradation.

groundwater $(62.3 \%)$, overgrazing (60.6\%), depletion of fish stocks $(41 \%)$, soil erosion (39\%), hazardous waste disposal (31.6\%), and floods (13.9\%).

Regarding the responsibility for mitigating environmental degradation, $38 \%$ of the respondents identified state and federal governments as having the highest degree of responsibility (Figure 4). This was followed by civil society $(18 \%)$, the general public $(18 \%)$, business and industry (14\%), and international organizations $(12 \%)$.

Figure 5 presents the respondents' opinions regarding the influence of civil society in the environmental decision-making process. Overall, $51.1 \%$ of the respondents believe civil society is slightly influential, $30.7 \%$ not at all influential, $4.2 \%$ somewhat influential, while only $14 \%$ believe civil society is either extremely or very influential in environmental decisions in Puntland. 


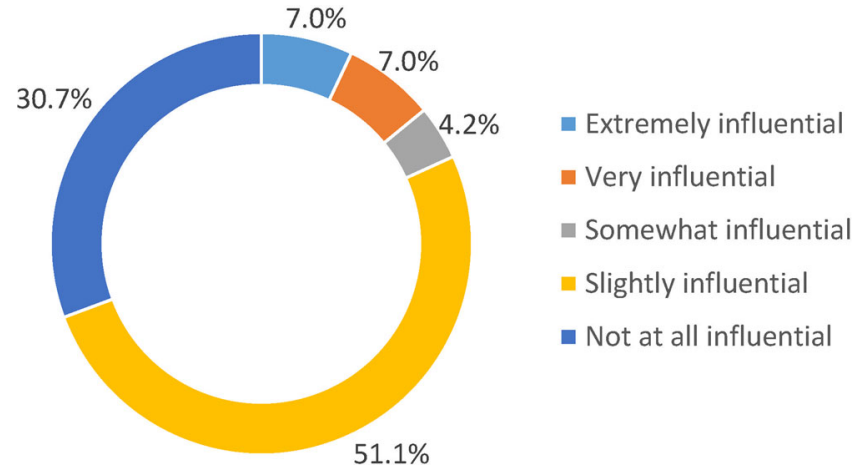

Figure 5. Perception of the respondents about the influence of civil society in environmental decisions.

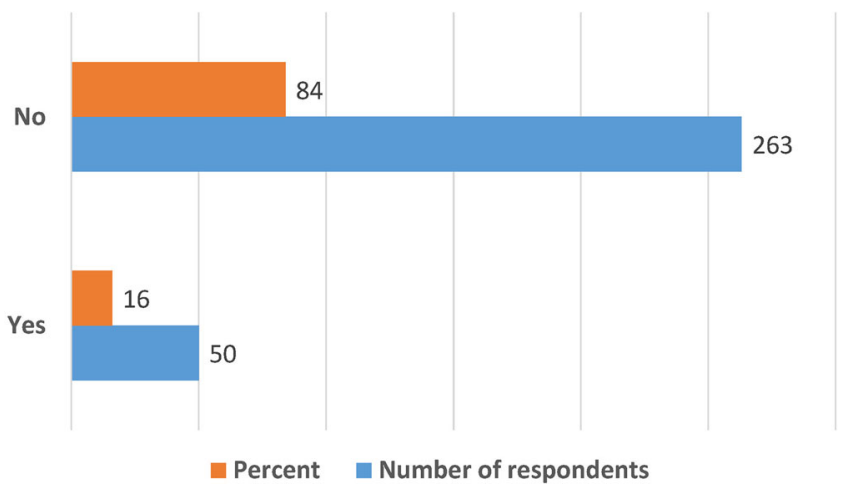

Figure 6. The participation of the respondents in environmental decision-making.

Respondents were also asked whether they have participated in an environmental decision-making process (Figure 6). We found a large difference in response, where $84 \%$ of the respondents indicated that they have never participated in an environmental decision-making process, while only $16 \%$ indicated that they have participated. Following up this question, respondents considered the causes of this inadequacy in participation as follows: $31 \%$ indicated that there are no government-citizen relationships in Puntland, 30\% perceive that the government does not consider civil society input as important, $15 \%$ perceive that civil society is not capable of contributing to decisions, $13 \%$ perceive that there is an absence of adequate resources to influence decisions, and $10 \%$ said it is costly and delays the decision-making process (Figure 7).

\subsection{Descriptive statistics and multiple regression}

The descriptive statistics for the selected variables are presented in Table 1. All the mean values of the variables were lower than the mid-point of 3 , indicating that the respondents in the survey largely showed a negative perception towards civil society participation. This can be inferred through limited access to information, a low level of consultation and lack of active participation that may negatively affect the environmental decisions. 


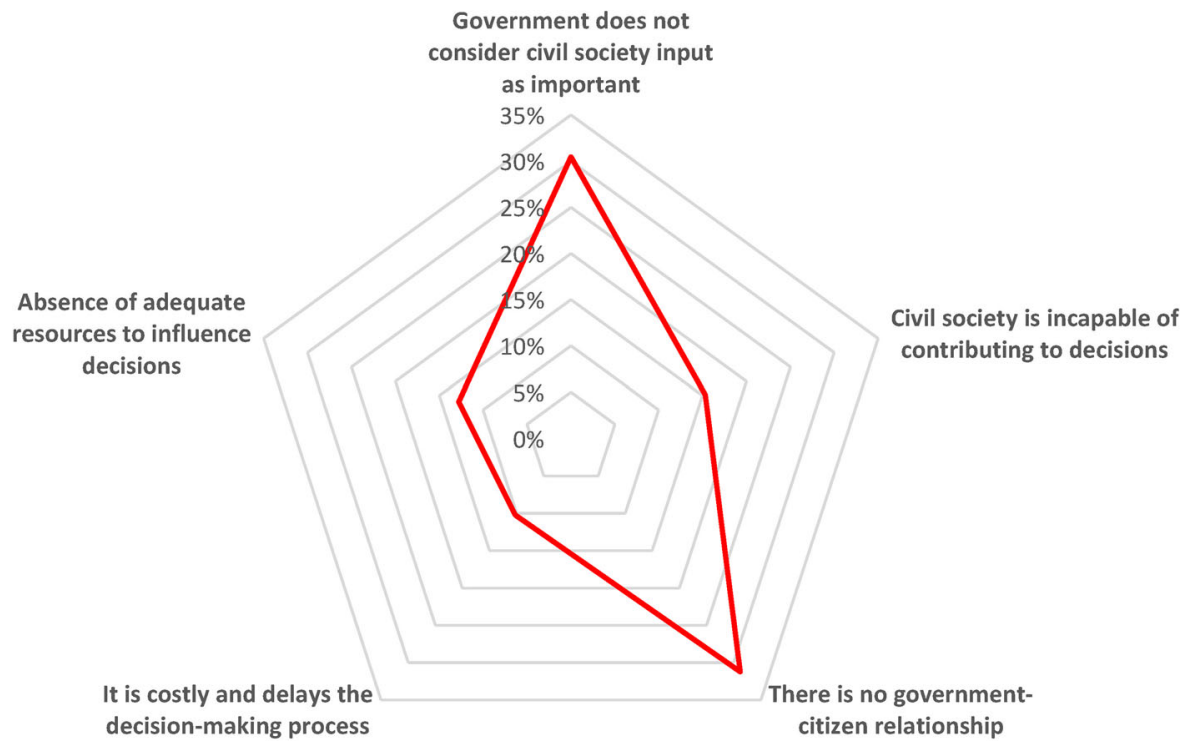

Figure 7. Perception of the respondents about the causes of civil society limited participation in environmental decision-making.

The Pearson correlations in Table 1 show that environmental decisions have a moderately positive correlation with both consultation $(r=0.345)$ and active participation $(r=0.509)$, whereas it has a weak positive correlation with information $(r=0.146)$. The correlations between all the variables show significant probability values $(P<0.05)$. VIF values were below 0.6 , which indicates that multicollinearity is not an issue in this study and further analysis can be applied.

In the first step of the forward regression we included information as an explanatory predictor in Model $1\left(\beta_{1}=0.146, P<0.05\right)$. The next explanatory variable was consultation, which was included in Model 2 and Model 3. It maintained a significant beta coefficient in Model $2\left(\beta_{2}=0.332, P<0.001\right)$, but decreased in magnitude in Model $3\left(\beta_{2}=0.189, P<0.001\right)$. The addition of the final variable, active participation, in Model 3 produced the highest $\beta$ value $\left(\beta_{3}=0.448, P<0.001\right)$, but this altered the sign of our first predictor, information, and rendered it insignificant $\left(\beta_{1}=-0.33\right.$, $P>0.05)$. Thus, we eliminated information from our model.

Model 3 resulted in a coefficient of variation $\left(R^{2}\right)$ of 0.281 , and was statistically significant $(F$-test $=41.7, P<0.001)$ (Table 3$)$. This indicates that $28 \%$ of the variance in environmental decisions is explained by the model. The remaining $72 \%$ could be due to other factors that are not part of our analysis.

As shown in Table 4, the backward stepwise regression excluded information from the analysis due to its poor performance in the forward regression phase. Model 2 shows consultation $\left(\beta_{2}=0.181, P<0.001\right)$ and active participation $(\beta 3=0.442$, $P<0.001)$ as statistically significant. Therefore, we reject the null hypothesis and accept the alternative hypothesis. The final model in Equation (2) shows that the two most important predictor contributors for environmental decisions are consultation $\left(X_{2}\right)$ and active participation $\left(X_{3}\right)$ :

$$
y=0.514+0.181 * X_{2}+0.442 * X_{3}
$$


Table 3. Step-wise forward regression analysis.

\begin{tabular}{lccc}
\hline Variable & Model 1 & Model 2 & Model 3 \\
\hline Information & $0.146^{*}$ & 0.42 & -0.33 \\
Consultation & & $0.332^{* * *}$ & $0.189^{* * *}$ \\
Active participation & $6.758^{*}$ & $21.274^{* * *}$ & $0.448^{* * *}$ \\
$F$-value & 0.018 & 0.115 & $41.722^{* * *}$ \\
$R^{2}$ & & 0.281 \\
\hline
\end{tabular}

Note: Dependent variable: environmental decisions.

${ }^{*} P \leq 0.05,{ }^{* *} P \leq 0.01,{ }^{* * *} P \leq 0.001$.

Table 4. Step-wise backward regression analysis.

\begin{tabular}{|c|c|c|c|c|c|}
\hline \multirow[b]{2}{*}{ Model } & \multicolumn{2}{|c|}{ Unstandardized coefficients } & \multicolumn{2}{|c|}{ Standardized coefficients } & \multirow[b]{2}{*}{$P$} \\
\hline & $B$ & Std. err. & $\beta$ & $T$ & \\
\hline 1. (Constant) & 0.567 & 0.151 & & 3.760 & 0.000 \\
\hline Information & -0.028 & 0.043 & -0.033 & -653 & 0.514 \\
\hline Consultation & 0.158 & 0.045 & 0.189 & 3.547 & 0.000 \\
\hline Active Participation & 0.440 & 0.052 & 0.448 & 8.530 & 0.000 \\
\hline 2. (Constant) & 0.514 & 0.127 & & 4.045 & 0.000 \\
\hline Consultation & 0.151 & 0.43 & 0.181 & 3.496 & 0.000 \\
\hline Active Participation & 0.434 & 0.051 & 0.442 & 8.553 & 0.000 \\
\hline
\end{tabular}

Note: Dependent variable: environmental decisions.

\section{Discussion}

\subsection{Degrees of participation in environmental decisions}

We evaluated the degrees of participation that exist in the study area in order to identify the ones that can have the most impact on the decisions to mitigate environmental degradation. The results indicated that information has the least contribution to environmental decisions and is inconsistent with previous studies (Langer, Decker, and Menrad 2017; Rollason et al. 2018; Tang, Wong, and Lau 2008). The possible reasons for this inconsistency can be explained as follows. First, participation in Somalia is often limited to the dissemination of information by means of holding workshops, which is a one-way type of communication where the government provides information without feedback. The participants in these workshops receive incentives if they participate. So, for the participants it becomes a means of earning income and for the government it is part of the process to legitimize their decisions. This form of participation is contrary to the fundamental principles of participation where governments hold participatory activities so that public input plays a valuable role in ensuring environmental decision-makers are aware of the full array of policy options (Richards, Allenby, and Compton 2001; Rowan-Robinson et al. 1996). In return, it eliminates potential conflicts that can hinder policy or project implementation. The "shadow participation" in which Somalia's public authorities offer a quid pro quo to gain public acceptance has been deemed by researchers as "problematic and challenging," (Armeni $2016,416)$ and "makes normative and practical rationalization of meaningful decisionmaking more fragile" (Armeni 2016; Lee and Abbot 2003). Thus, we assume that the respondents are dissatisfied with this form of participation and a mixture of degrees of participation is needed, since information is considered the lowest degree of participation (Arnstein 1969; Collins and Ison 2009; Rollason et al. 2018). These are the probable reasons why information shows a low contribution to environmental decisions in our model. 
Our results also revealed that consultation has a moderately positive contribution to environmental decisions. This is in line with previous research that found consultation of civil society in the early stages of the decision-making improves environmental decisions (Adomokai and Sheate 2004; Langer, Decker, and Menrad 2017; Momtaz and Gladstone 2008). Additionally, consultation passively changes the attitude of organized citizens towards the government, leading to public acceptance of decisions since it generates some level of confidence in the decision-making process. However, not all consultation methods have produced and solved complex environmental problems. Our results indicate that face-to-face consultation with civil society seems to have a positive influence on the quality of environmental decisions. This is consistent with Newig and Fritsch (2009) who addressed the environmental effectiveness of participatory and multi-level governance using a comparative meta-analysis of 47 case studies on environmental decision-making in North America and Europe.

It is plausible that respondents perceived active participation to have the highest contributions to environmental decisions, since this degree of participation promotes empowerment of local leadership and decision-making control. This is consistent with earlier findings (Arnstein 1969; O'Faircheallaigh 2010; Sinclair and Diduck 2017; Vanclay 2003) that active participation of civil society as a stakeholder can create a more equitable distribution of decision-making control by transforming the existing decision structure. This also generates the establishment of partnerships that could help public authorities monitor environmental policies and assist in the design, implementation and evaluation of environmental regulations. Contrary to Spyke (1999), we found that the structure of participation to be partially not coordinated, since information becomes insignificant when consultation and active participation are in the model. This can be explained within the context of post-conflict societies that access to information is not as important as issues of consultation and active participation. Thus, the imported one-size-fits-all approach to participation in environmental decision-making common in Western countries is inapplicable in this context.

\subsection{Level of environmental awareness}

We find a high level of environmental awareness among our participants (Figure 2). Our initial model included information on policy provided by the government in a passive one-way direction (Equation (1)). The stepwise regression analysis eliminated information as an insignificant and non-contributing variable to the overall model. This suggests that (1) the participants acquire information about the condition of their local environment from sources other than the government, or (2) that they were personally exposed to different forms of environmental degradation (Figure 3 and Supplementary material Figure S1). Previous studies in developing countries (Räthzel and Uzzell 2009) and in Somalia (Oduori, Alim, and Gomes 2006) have reported similar results. However, since our study targeted organized citizens we infer that the environmental awareness of civil society alone cannot be sufficient to evaluate general public awareness, but more inclusive grassroots awareness could be more meaningful, as this will involve members of society outside the core group that we sampled.

\subsection{Perceptions of environmental degradation}

We find that land degradation, deforestation, and drought are the most pressing environmental concerns in Somalia in general, and Puntland in particular (Figure 3), which is corroborated by previous research (Ogallo et al. 2018; Oduori, Alim, and Gomes 
2006; Oduori et al. 2011; Rembold et al. 2013). As reported by previous studies in Somalia, this is the result of unsustainable practices, over-dependence on scarce resources and ineffective governance regulations. For instance, because of weak forest regulations Somalia has experienced widespread deforestation for the production of charcoal (Oduori et al. 2011). These unsustainable practices have triggered conflicts between clans that favor providing the tree foliage as fodder for their livestock and clans that trade in wood and for whom the trees are a lucrative business. This is perhaps why most respondents regarded environmental problems as an issue personally important to them (Supplementary material Figure S2).

Similar conflicts over resources have also occurred nearshore as overharvesting of fish stocks in unregulated fishing activities caused the destruction of foreign fishing boats by local fishermen (UNEP 2005). This echoes earlier findings that have been reported from post-conflict settings where security, humanitarian assistance, political reconciliation, and economic reconstruction are often considered as the most pressing priorities, whereas the mitigation of environmental degradation is often not integrated into the recovery process (Beevers 2012; Bruch et al. 2008; Suarez, Árias-Arévalo, and Martínez-Mera 2018). The post-conflict recovery process of Somalia could be undermined by these developments. In the short term, failure to address environmental degradation could exacerbate human suffering and escalate vulnerability to extreme weather events. In the long term, it may threaten the successful functioning of political, economic and societal institutions essential for durable peace (Conca and Wallace 2009).

Our respondents identify the tackling and mitigating of environmental degradation as a collective responsibility where both state and federal governments take the lead (Figure 4). This means that reversing environmental degradation in Somalia can be best handled when all actors who are part of the problem are also included as part of the solution. This is the notion of collaborative governance that gained momentum in global environmental governance after the adoption of Agenda 21 at the Rio Declaration in 1992.

\subsection{Influence and participation of civil society}

Our results show a less influential civil society with limited participation in the environmental decisions of the Puntland State of Somalia (Figures 6 and 7). The fact that $84 \%$ of our respondents have never participated in environmental decision-making processes indicates a major challenge to the already fragile and weak institutional setups that exist in the region. This also indicates that international agencies such as The World Bank and International Monetary Fund, and foreign donors who provide the bulk of the Somali government's revenue, and accommodate rebuilding the capacity of Somali public institutions, have neglected the full participation of civil society as a cornerstone of the decision-making process. Moreover, we asked our respondents a follow-up question about their perception towards the causes of the limited participation in Puntland and they indicated the two most important causes as (1) the government not considering public or civil society input as valuable and (2) lack of a meaningful government-citizen relationship. This is consistent with previous findings reported from former Soviet Union countries that had undergone similar periods of social and political upheaval (Carmin 2003). This means that the legacy gridlock approach of "decide, announce, and defend" decision-making process of the late President Mohamed Siyaad Barre is still dominant in Somalia. 


\section{Conclusions}

This study explored the participation of civil society in decisions to mitigate environmental degradation in the post-conflict setting of the Puntland State of Somalia. Our results revealed that information contributes the least to environmental decisions, and consultation and active participation had moderate and high contributions, respectively. The respondents ranked the top three environmental problems in Puntland as land degradation, deforestation, and drought relating to the scarcity of rainfall. Most of the respondents identified both state and federal governments as having the highest responsibility for mitigating environmental degradation.

Generally speaking, the challenge of maintaining and improving the environment is undeniably one of the most pressing and demanding problems confronting post-conflict countries. But it is also worth noting that the situation in the Somali context is exacerbated by the failure of public authorities to provide basic fundamental measures to solve environmental degradation. Both the federal and state governments have failed to propose successful mitigation measures to control human activities that degrade the environment, and have failed to reform existing legislation and enact new laws that protect the environment.

On the other hand, there is no indication that the current participation of civil society would improve the quality of the decisions to mitigate environmental degradation in Puntland because of predetermined outcomes induced by "shadow participation". This further spoils the meaning of participation that would later result in the impairment of a public institution's credibility. Hence, to reach sustainable and meaningful environmental decisions, we propose a more collaborative bottom-up participation approach where the government legally institutionalizes civil society to actively participate in the environmental decision-making process.

Although the rate of recovery of a post-conflict country is dependent on the security situation, a clear-cut concept to tackle both environmental degradation and conflicts could be the incorporation of "environmental cooperation" into the peace-building process. This would enable the general public federal government, state government, civil society, philanthropists, environmental policy-making experts and international organizations to share the responsibilities for tackling environmental degradation and conserve the environment for the next generation.

This study provides an important exploratory insight into public perceptions towards environmental degradation and decision-making in post-conflict Somalia. We showed that participation of civil society in environmental decision-making in Somalia is a complex phenomenon. Our results indicate that effective environmental conservation in Somalia requires inclusive grassroots awareness to better inform the majority of the population. Importantly, the study highlighted the need to assess the role of the general public regardless of their levels of literacy in order to assess the full spectrum of environmental decision-making in Somalia. Thus, this study forms an important foundation for future research at the nexus of the environment, people, and public policy in post-conflict societies in general and Somalia in particular.

There were some challenges and limitations that need to be mentioned. One challenge was linked to undertaking research in a post-conflict setting. As such, there were multiple security concerns, particularly in the disputed areas between Somaliland and Puntland, as well as within Puntland itself. These concerns could have contributed to the low response rate of civil society members outside the major towns to the printed survey questionnaires. One limitation was that we used cross-sectional data that may bring a social 
interest bias, since the associations among the variables have not been thoroughly tested. We aim to rectify this in future studies by applying a strictly experimental set-up that accounts for this. Another limitation was that our sample size is rather small and the respondents are fairly young and educated. Thus, we recommend that caution be taken when generalizing our findings. We collected our sample data from the organized citizens in the Puntland State of Somalia, so our results cannot represent the entire Somali population. That said, these limitations and challenges do not invalidate this study, but will form an important launch pad for more comprehensive studies for the entire country.

\section{Note}

1. http://pl.statistics.so/population-of-puntland/

\section{Acknowledgements}

The authors thank the anonymous reviewers for providing detailed comments that improved the manuscript.

\section{Disclosure statement}

No potential conflict of interest was reported by the authors.

\section{Supplemental data}

Supplemental data for this article can be accessed here https://doi.org/10.1080/09640568. 2019.1685957

\section{Funding}

This work was supported by the Chinese Scholarship Council for financial support [CSC no. 1741159C74]; the China Postdoctoral Science Foundation [2018M632552]; the Chinese Academy of Science (CAS) providing the CAS-Foreign Young Scientist Award [2018FYB0002]; and the Swedish Research Council [Grant no. 2018-00430].

\section{ORCID}

Osman M. Jama (D) https://orcid.org/0000-0002-7345-2812

Balal Yousaf (D) https://orcid.org/0000-0003-2732-2176

Abdulhakim M. Abdi (D) http://orcid.org/0000-0001-6486-8747

\section{References}

Abdi, A. M., A. Vrieling, G. T. Yengoh, A. Anyamba, J. W. Seaquist, C. C. Ummenhofer, and J. Ardö. 2016. "The El Niño - La Niña Cycle and Recent Trends in Supply and Demand of Net Primary Productivity in African Drylands." Climatic Change 138 (1-2): 111-125. doi: 10.1007/s10584-016-1730-1.

Adano, W. R., T. Dietz, K. Witsenburg, and F. Zaal. 2012. "Climate Change, Violent Conflict and Local Institutions in Kenya's Drylands." Journal of Peace Research 49 (1): 65-80. doi: $10.1177 / 0022343311427344$. 
Adomokai, R., and W. R. Sheate. 2004. "Community Participation and Environmental DecisionMaking in the Niger Delta." Environmental Impact Assessment Review 24 (5): 495-518. doi: 10.1016/j.eiar.2004.01.002.

AfDB. 2016. From Fragility to Resilience Managing Natural Resources in Fragile Situations in Africa. Abidjan, Côte D'Ivoire: African Development Bank Group.

Aitken, M. 2010. "A Three-Dimensional View of Public Participation in Scottish Land-Use Planning: Empowerment or Social Control?” Planning Theory 9 (3): 248-264. doi:10.1177/ 1473095210366193.

Ali, S. H. 2013. Ecological Cooperation in South Asia: The Way Forward. Washington, DC: New America Foundation.

Armeni, C. 2016. "Participation in Environmental Decision-Making: Reflecting on Planning and Community Benefits for Major Wind Farms." Journal of Environmental Law 28 (3): 415-441. doi:10.1093/jel/eqw021.

Arnstein, S. R. 1969. "A Ladder of Citizen Participation." Journal of the American Institute of Planners 35 (4): 216-241. doi:10.1080/01944366908977225.

Beevers, M. D. 2012. "Forest Resources and Peacebuilding: Preliminary Lessons from Liberia and Sierra Leone." In High-Value Natural Resources and Post-Conflict Peacebuilding, edited by Päivi Lujala and Siri Aas Rustad, 367-390. Oxford and New York: Earthscan.

Beierle, T. C., and J. Cayford. 2002. Democracy in Practice: Public Participation in Environmental Decisions. Washington, DC: Resources for the Future. doi:10.5860/choice. 40-1164.

Betsill, M. M., and C. Elisabeth. 2008. NGO Diplomacy: The Influence of Nongovernmental Organizations in International Environmental Negotiations. Cambridge, MA: The MIT Press.

Bogale, A., and B. Korf. 2007. "The Journal of Development to Share or Not to Share? (Non-) Violence, Scarcity and Resource Access in Somali Region, Ethiopia." The Journal of Development Studies 43 (4): 743-765. doi:10.1080/00220380701260093.

Boyle, J. 1998. "Cultural Influences on Implementing Environmental Impact Assessment: Insights from Thailand, Indonesia, and Malaysia." Environmental Impact Assessment Review 18 (2): 95-116. doi:10.1016/S0195-9255(97)00082-6.

Bruce, J., and W. A. Chambers. 2002. "Questionnaire Surveys." Anaesthesia 57 (11): 1049-1051. doi:10.1046/j.1365-2044.2002.02961.x.

Bruch, C., D. Jensen, M. Nakayama, J. Unruh, R. Gruby, and R. Wolfarth. 2008. "Post-Conflict Peace Building and Natural Resources." Yearbook of International Environmental Law 19 (1): 58-96. doi:10.1093/yiel/19.1.58.

Buchanan, K. S. 2013. "Contested Discourses, Knowledge, and Socio-Environmental Conflict in Ecuador." Environmental Science and Policy 30: 19-25. doi:10.1016/j.envsci.2012.12.012.

Burt, M., and B. J. Keiru. 2011. "Strengthening Post-Conflict Peacebuilding Through Community Water-Resource Management: Case Studies from Democratic Republic of Congo, Afghanistan and Liberia." Water International 36 (2): 232-241. doi:10.1080/ 02508060.2011 .558885 .

Carius, A. 2006. "Environmental Peacebuilding: Environmental Cooperation as an Instrument of Crisis Prevention and Peacebuilding." Paper presented at the Conference on the Human Dimensions of Global Environmental Change in Berlin, November 17-18.

Carmin, J. 2003. "Non-Governmental Organisations and Public Participation in Local Environmental Decision-Making in the Czech Republic." Local Environment 8 (5): 541-552. doi:10.1080/1354983032000143699.

Challies, E., J. Newig, E. Kochskämper, and N. W. Jager. 2017. "Governance Change and Governance Learning in Europe: Stakeholder Participation in Environmental Policy Implementation." Policy and Society 36 (2): 288-303. doi:10.1080/14494035.2017.1320854.

Charnley, S., and B. Engelbert. 2005. "Evaluating Public Participation in Environmental Decision-Making: EPA's Superfund Community Involvement Program." Journal of Environmental Management 77 (3): 165-182. doi:10.1016/j.jenvman.2005.04.002.

Collins, K., and R. Ison. 2009. "Jumping off Arnstein's Ladder: Social Learning as a New Policy Paradigm for Climate Change Adaptation." Environmental Policy and Governance 373: 358-373. doi:10.1002/eet.523.

Conca, K., and G. D. Dabelko. 2002. Environmental Peacemaking. Washington, DC: Woodrow Wilson Center Press. 
Conca, K., and J. Wallace. 2009. "Environment and Peacebuilding in War-Torn Societies: Lessons from the UN Environment Programme's Experience with Postconflict Assessment." Global Governance: A Review of Multilateralism and International Organizations 15 (4): 485-504. doi:10.1163/19426720-01504008.

Cooper, L. M., and J. A. Elliott. 2003. "Public Participation and Social Acceptability in the Philippine Eia Process." Journal of Environmental Assessment Policy and Management 2 (3): 339-367. doi:10.1142/S1464333200000400.

EUSU. 2012. Strengthening Civil Society in Somalia: Developing a Comprehensive Strategy. Brussels, Belgium: The EU Somalia Unit.

Fagan, A. 2006. "Neither 'North' nor 'South': The Environment and Civil Society in PostConflict Bosnia-Herzegovina.” Environmental Politics 4016 (September): 787-802. doi:10. 1080/09644010600937215.

Farrell, J. 2017. The Battle for Yellowstone: Morality and the Sacred Roots of Environmental Conflict. Vol. 66. Princeton, NJ: Princeton University Press.

Francois, M. 2017. "Role of Civil Society Organizations in Conflict and Post-Conflict Situations in Rwanda." Journal of African Conflicts and Peace Studies 3 (2): 16-37. doi:10.5038/ 2325-484X.3.2.1096.

Gemmil, B., and A. Bamidele-Izu. 2002. "The Role of NGOs and Civil Society in Development and Poverty Reduction.” In Global Environmental Governance, edited by Daniel C. Esty and Maria H. Ivanova 1-40. New Haven, CT: Yale School of Forestry and Environmental Studies. http://environment.research.yale.edu/documents/downloads/a-g/gemmill.pdf.

Harvey, P. 1998. "Rehabilitation in Complex Political Emergencies: Is Rebuilding Civil Society the Answer?" Disasters 22 (3): 200-217. doi:10.1111/1467-7717.00087.

Ide, T. 2017. "Space, Discourse and Environmental Peacebuilding." Third World Quarterly 38 (3): 544-562. doi:10.1080/01436597.2016.1199261.

Ide, T. 2018. "The Impact of Environmental Cooperation on Peacemaking: Definitions, Mechanisms, and Empirical Evidence.” International Studies Review 21 (3): 327-346. doi: 10.1093/isr/viy014.

Kakabadse, Y., J. Caillaux, and J. Dumas. 2016. "The Peru and Ecuador Peace Park: One Decade after the Peace Settlement." In Governance, Natural Resources, and Post-Conflict Peacebuilding, edited by Carl Bruch, Carroll Muffett, and Sandra S. Nichols, 817-825. Abingdon, UK: Routledge.

Langer, K., T. Decker, and K. Menrad. 2017. "Public Participation in Wind Energy Projects Located in Germany: Which Form of Participation Is the Key to Acceptance?" Renewable Energy 112: 63-73. doi:10.1016/j.renene.2017.05.021.

Lee, M., and C. Abbot. 2003. "The Usual Suspects? Public Participation under the Aarhus Convention." Modern Law Review 66 (1): 80-108. doi:10.1111/1468-2230.6601004.

Loehlin, J. C. 2004. Latent Variable Models: An Introduction to Factor, Path, and Structural Analysis. 4th ed. New York: Routledge.

Malinowski, R. L. 2014. Role of the Civil Society in Peace Support Operations in South Sudan and Somalia: The Component of Peacebuilding. Nairobi, Kenya: International Peace Support Training Centre.

Marchant, R., C. Mumbi, S. Behera, and T. Yamagata. 2007. "The Indian Ocean Dipole: The Unsung Driver of Climatic Variability in East Africa." African Journal of Ecology 45 (1): 4-16. doi:10.1111/j.1365-2028.2006.00707.x.

Menkhaus, K. 2003. "State Collapse in Somalia: Second Thoughts." Review of African Political Economy 30 (97): 405-422. doi:10.1080/03056244.2003.9659774.

Menkhaus, K. 2007. "Governance Without Government in Somalia: Spoilers, State Building, and the Politics of Coping." International Security 31 (3): 74-106. doi:10.1162/isec.2007.31.3.74.

Menkhaus, K. 2014. "State Failure, State-Building, and Prospects for a 'Functional Failed State' in Somalia." Annals of the American Academy of Political and Social Science 656 (1): 154-172. doi:10.1177/0002716214547002.

Momtaz, S., and W. Gladstone. 2008. "Ban on Commercial Fishing in the Estuarine Waters of New South Wales, Australia: Community Consultation and Social Impacts." Environmental Impact Assessment Review 28 (2-3): 214-225. doi:10.1016/j.eiar.2007.03.001.

Newig, J. 2007. "Does Public Participation in Environmental Decisions Lead to Improved Environmental Quality? Towards an Analytical Framework." International Journal of 
Sustainability Communication 1 (15171): 51-71. https://nbn-resolving.org/urn: nbn: de:0168-ssoar-431965.

Newig, J., E. Challies, N. W. Jager, E. Kochskaemper, and A. Adzersen. 2018. "The Environmental Performance of Participatory and Collaborative Governance: A Framework of Causal Mechanisms." Policy Studies Journal 00 (00): 1-29. doi:10.1111/psj.12209.

Newig, J., and O. Fritsch. 2009. "Environmental Governance: Participatory, Multi-Level - and Effective?" Environmental Policy and Governance 214: 197-214. doi:10.1002/eet.509.

O'Faircheallaigh, C. 2010. "Public Participation and Environmental Impact Assessment: Purposes, Implications, and Lessons for Public Policy Making." Environmental Impact Assessment Review 30 (1): 19-27. doi:10.1016/j.eiar.2009.05.001.

Oduori, S. M., M. S. Alim, and N. Gomes. 2006. Environmental Study of Degradation in the Gebi Valley and Sool Plateau, Sanaag Region of Northern Somalia. Nairobi: Fao-Swalim.

Oduori, S. M., F. Rembold, O. H. Abdulle, and R. Vargas. 2011. "Assessment of Charcoal Driven Deforestation Rates in a Fragile Rangeland Environment in North Eastern Somalia Using Very High Resolution Imagery." Journal of Arid Environments 75 (11): 1173-1181. doi:10.1016/j.jaridenv.2011.05.003.

OECD. 2001. Citizens as Partners. Paris, France: OECD.

Ogallo, L., K. Mwangi, P. Omondi, G. Ouma, and G. Wayumba. 2018. "Land Cover Changes in Lower Jubba Somalia." American Journal of Climate Change 07 (03): 367-387. doi:10. 4236/ajcc.2018.73022.

Ogden, L. E. 2018. "Environmental Peacebuilding.” BioScience 68 (3): 157-163. doi:10.1093/ biosci/bix 159 .

Paffenholz, T., and C. Spurk. 2006. "Civil Society, Civic Engagement, and Peacebuilding." Social Development Papers: Conflict Prevention and Reconstruction 36: 10-55.

Parver, C., R. Wolf, C. Parver, and R. Wolf. 2008. "Civil Society's Involvement in Post-Conflict Peacebuilding." International Journal of Legal Information 1 (1): 51-79. doi:10.1017/ S0731126500002705.

Räthzel, N., and D. Uzzell. 2009. "Changing Relations in Global Environmental Change." Global Environmental Change 19 (3): 326-335. doi:10.1016/j.gloenvcha.2009.05.001.

Reed, M. S. 2008. "Stakeholder Participation for Environmental Management: A Literature Review." Biological Conservation 141 (10): 2417-2431. doi:10.1016/j.biocon.2008.07.014.

Rembold, F., S. M. Oduori, H. Gadain, and P. Toselli. 2013. "Mapping Charcoal Driven Forest Degradation During the Main Period of al Shabaab Control in Southern Somalia." Energy for Sustainable Development 17 (5): 510-514. doi:10.1016/j.esd.2013.07.001.

Richards, D. J., B. R. Allenby, and W. Dale Compton. 2001. Information Systems and the Environment. Washington, DC: The National Academies Press.

Rollason, E., L. J. Bracken, R. J. Hardy, and A. R. G. Large. 2018. "Evaluating the Success of Public Participation in Integrated Catchment Management." Journal of Environmental Management 228 (May): 267-278. doi:10.1016/j.jenvman.2018.09.024.

Rowan-Robinson, J., A. Ross, W. Walton, and J. Rothnie. 1996. "Public Access to Environmental Information: A Means to What End?" Journal of Environmental Law 8 (1): 19-42. doi:10.1093/jel/8.1.19.

Ruckstuhl, S. M. 2010. Enabling Environmental Peacebuilding: An Analysis of Products and Factors in Four Project Cases. Fairfax, VA: George Mason University.

Salamon, L.- M., S.W. Sokolowski, and R. List. 2003. Global Civil Society. An Overview. Baltimore, Maryland: Center for Civil Society Studies, Institute for Policy Studies, The John Hopkins University.

Sinclair, A. J., and A. P. Diduck. 2017. "Reconceptualizing Public Participation in Environmental Assessment as EA Civics." Environmental Impact Assessment Review 62: 174-182. doi:10.1016/j.eiar.2016.03.009.

Spyke, N. P. 1999. "Public Participation in Environmental Decision-making at the New Millennium." Environmental Affairs Law Review 26 (2): 263-314.

Suarez, A., P. A. Árias-Arévalo, and E. Martínez-Mera. 2018. "Environmental Sustainability in Post-Conflict Countries: Insights for Rural Colombia." Environment, Development and Sustainability 20 (3): 997-1015. doi:10.1007/s10668-017-9925-9.

Taher, T., B. Bruns, O. Bamaga, A. Al-Weshali, and F. Van Steenbergen. 2012. "Local Groundwater Governance in Yemen: Building on Traditions and Enabling Communities to Craft New Rules." Hydrogeology Journal 20 (6): 1177-1188. doi:10.1007/s10040-012-0863-1. 
Tang, B.-S., S.-W. Wong, and M. C. -H. Lau. 2008. "Social Impact Assessment and Public Participation in China: A Case Study of Land Requisition in Guangzhou." Environmental Impact Assessment Review 28 (1): 57-72. doi:10.1016/j.eiar.2007.03.004.

UNDP. 2001. Human Development Report: Somalia. Nairobi: United Nations Development Programme.

UNDP. 2014. Somalia (Puntland and Somaliland) Case Study. Nairobi: United Nations Development Programme.

UNEP. 2005. The State of the Environment in Somalia: A Desk Study. Geneva, Switzerland: United Nations Environmental Programme.

UNICEF. 2017. Education in Somalia: July 2017 Update. United Nations Children's Fund. https://www.unicef.org/somalia/SOM_resrources_educationbulletinQ22017.pdf.

USAGM. 2013. Media Use in Somalia. Washington, DC: United States Agency for Global Media/Gallup.

Vanclay, F. 2003. "International Principles for Social Impact Assessment." Impact Assessment and Project Appraisal 21 (1): 5-12. doi:10.3152/147154603781766491.

Wang, S., J. Wang, S. Lin, and J. Li. 2019. "Public Perceptions and Acceptance of Nuclear Energy in China: The Role of Public Knowledge, Perceived Benefit, Perceived Risk and Public Engagement." Energy Policy 126: 352-360. http://www.sciencedirect.com/science/ article/pii/S0301421518307699. doi:10.1016/j.enpol.2018.11.040.

Welp, M., B. Kasemir, and C. C. Jaeger. 2009. "Citizens' Voices in Environmental Policy." In Public Participation and Better Environmental Decisions: The Promise and Limits of Participatory Processes for the Quality of Environmentally Related Decision-Making, edited by C. H. J. M. Frans, 21-34. Dordrecht: Springer Netherlands. 